Erratum

\title{
Erratum: Functional analysis of MKP-1 and MKP-2 in breast cancer tamoxifen sensitivity
}

\author{
Kelly K. Haagenson ${ }^{1,2}$, Jessica Wei Zhang ${ }^{2}$, Zhengfan $X \mathbf{u}^{2}$, Malathy P.V. Shekhar ${ }^{1,2,3}$ \\ and Gen Sheng $\mathbf{W u}^{1,2,3}$ \\ ${ }^{1}$ Department of Oncology, Wayne State University School of Medicine, Detroit, MI \\ 2 Barbara Ann Karmanos Cancer Institute, Detroit, MI \\ ${ }^{3}$ Department of Pathology, Wayne State University School of Medicine, Detroit, MI \\ Published: October 16, 2018
}

Copyright: Haagenson et al. This is an open-access article distributed under the terms of the Creative Commons Attribution License 3.0 (CC BY 3.0), which permits unrestricted use, distribution, and reproduction in any medium, provided the original author and source are credited.

This article has been corrected: During production, the ending page number for this article was listed incorrectly. The page count has now been adjusted to show the proper pagination.

Original article: Oncotarget. 2014; 5:1101-1110. https://doi.org/10.18632/oncotarget.1795 